\title{
King Conrad III in the Byzantine Empire: A Foil for Native Imperial Virtue
}

\author{
Jason T. Roche
}

Between the end of December and the German assembly at Regensburg in February 1147, the emperor-elect of the Holy Roman empire, the German king Conrad III of Staufen, and many other men from the higher German nobility had vowed to defend the Latin Church in the Levant. It was perhaps at this assembly that the decision was made to follow the pilgrimage route to the Holy Land via Hungary, the Balkans (Byzantine territory) and Constantinople. A heterogeneous group comprised mainly of Franconians, Bavarians and Swabians subsequently set out from Nuremberg for Constantinople in the middle of May 1147. ${ }^{1}$ Later that month the army gathered at Regensburg where Conrad and presumably many other nobles with their retainers embarked upon ships to descend the River Danube. The army eventually reached Brandiz on the Byzantine border around July $20 .^{2}$

At this juncture, there was a close relationship between the Byzantine emperor, Manuel I Komnenos, and the German imperial house of Staufen. Manuel's father, John II Komnenos, had made an alliance with the German King Lothar III of Supplinburg against Roger II, the king of Sicily. John looked to renew it with Lothar's successor, Conrad III of Staufen, by means of a proposed marriage alliance. Manuel's subsequent marriage to Conrad's adopted daughter, Bertha-Eirene of Sulzbach, sealed the alliance in 1146. It has been suggested that Conrad's crusade must have temporarily dissolved this alliance; certainly, the passage through Byzantine territory of an army nominally headed by the German king could not have been incorporated into the terms that were concluded with Manuel's marriage to Bertha-Eirene. ${ }^{3}$

1 'Annales Palidenses', ed. Georg H. Pertz, in MGH SS, 16: 48-98 (here 82); 'Sigeberti Continuatio Praemonstratensis', ed. Ludwig Konrad Bethmann, in MGH SS, 6: 447-56 (here 453); William of Tyre, Chronique, ed. R. B. C. Huygens (Turnhout, 1986), p. 741; Otto of Freising, Continued by Rahewin, Gesta Frederici seu rectius Cronica, ed. Franz-Josef Schmale, trans. Adolf Schmidt, 2nd edn (Darmstadt, 1974), I.4547 (pp. 216-19) and The Deeds of Frederick Barbarossa, trans. Charles Christopher Mierow (New York, 1953), pp. $78-79$.

2 Odo of Deuil, De profectione Ludovici VII in orientem: The Journey of Louis VII to the East, ed. and trans. Virginia Gingerick Berry (New York, 1948), pp. 32-34, 40; Otto of Freising, Gesta Frederici, I.45-47 (pp. 216-19) and The Deeds of Frederick Barbarossa, pp. 78-79; Gerhoh of Reichersberg, 'De investigatione Antichristi liber I', ed. Ernst Sackur, in MGH Libelli de lite imperatorum et pontificum saeculis XI. et XII. conscripti, ed. Ernst Dümmler and others, 3 vols (Hannover, 1891-97), 3: 304-94 (here 374); 'Annales Palidenses', p. 82; 'Annales Herbipolenses', ed. Georg Pertz, in MGH SS, 16: 1-12 (here 4); Helmold of Bosau, 'Chronica Slavorum', ed. Heinz Stoob, Ausgewählte Quellen zur deutschen Geschichte des Mittelalters, 19 (Darmstadt, 2008), I.65 (pp. 216-17); William of Tyre, Chronique, p. 741; William of Newburgh, The History of English Affairs: Book 1, ed. and trans. Patrick Gerard Walsh and M. J. Kennedy (Warminster, 1988), p. 92; 'Historia Welforum Weingartensis', ed. Ludwig Weiland, in MGH SS, 21: 454-71 (here 468).

${ }^{3}$ Ralph-Johannes Lilie, Byzantium and the Crusader States, 1096-1204, trans. J. C. Morris and Jean E. Ridings (Oxford, 1993), pp. 148-49, 151-52; Paul Magdalino, The Empire of Manuel I Komnenos, 1143-1180 
It has long been held that the German march through Byzantine territory and the crusaders' stay outside the Byzantine capital posed significant threats to Constantinople's security, were characterised by gratuitous plunder and destruction, and that they gave rise to mutual hostility between Conrad III and Manuel Komnenos. These conventional notions stem from the work of Bernard Kugler, Ferdinand Chalandon and Steven Runciman, and they are heavily dependent upon literal readings of the Latin text of Odo of Deuil and the Greek narratives of Niketas Choniates and John Kinnamos in particular. ${ }^{4}$ This article will highlight a number of obvious concerns with the well-known Greek sources including the lack of supporting data for the testimonies they provide and the ways in which rhetorical conventions and the authors' agenda influence their evidence. Through the exposition of two Greek verse encomia composed by the so-called 'Manganeios Prodromos', the article takes particular issue with John Kinnamos's testimony. ${ }^{5}$ As will be seen, an appreciation of the eulogistic aims and rhetorical methods of the verse encomiasts, and an understanding of the ways in which the encomiastic rhetorical tradition is evident throughout the Greek narratives are essential to an interpretation of the Germans' advance in the Byzantine empire.

At its most fundamental level, the production and presentation of a Greek verse encomium, that is, a rhetorical court panegyric most frequently composed in veneration of the Byzantine emperor, involved a process whereby the encomiast presented his poem in the theatre of a formal or informal court assembly as a gift to the venerated individual. The encomium was usually offered in the expectation of favours or as an expression of gratitude for favours rendered previously. It is often impossible to ascertain whether the emperor's actions, policies, priorities or his desired image of himself determined what was eulogised. The encomiasts may have chosen to emphasise what would be pleasing for the emperor to hear. This in turn may or may not have also reflected the desires of the individual encomiast or the groups with which he identified. What is clear is that the emperor's person and concerns provided the subject matter for the encomia, which in turn provided the means for the emperor to air and make public his interests and concerns. As Paul Magdalino has

(Cambridge, 1993), pp. 38-40, 42-43, 48. Bertha, known as Eirene to the Greeks, was Conrad's sister-in-law at the time of his marriage negotiations with John II Komnenos. However, at some point before Bertha-Eirene's marriage to John's fourth son, Manuel, Conrad appears to have adopted her as his daughter. For the most reliable reference to Bertha as Conrad's daughter, see Otto of Freising, Gesta Frederici, I.25-27 (pp. 168-81) and The Deeds of Frederick Barbarossa, pp. 54-59.

${ }^{4}$ Bernard Kugler, Studien zur Geschichte des Zweiten Kreuzzugs (Stuttgart, 1866), pp. 119-47; Ferdinand Chalandon, Jean II Comnène (1118-1143) et Manuel I Comnène (1143-1143), 2 vols (Paris, 1912), 2: 263-81, 286-88; Steven Runciman, A History of the Crusades, 3 vols (Cambridge, 1951-1954), 2: 260-63, 266-68, 27475; Odo of Deuil, De profectione Ludovici VII in orientem; John Kinnamos, 'Epitome rerum ab Ioanne et Alexio Comnenis Gestarum', ed. August Meineke, in Corpus Scriptorum Historiae Byzantinae, ed. Barthold Georg Niebuhr, 50 vols (Bonn, 1828-97), 13: 1-251; John Kinnamos, Deeds of John and Manuel Comnenus, trans. Charles M. Brand (New York, 1976); Niketas Choniates, Nicetae Choniatae Historia, ed. Jan-Louis van Dieten, 2 vols (Berlin, 1975); Niketas Choniates, O City of Byzantium, Annals of Niketas Choniates, trans. Harry J. Magoulias (Detroit, 1984).

5 Manganeios Prodromos, Poems 20 and 24, ed. and trans. Elizabeth Jeffreys and Michael Jeffreys (unpublished). I am greatly indebted to Elizabeth and Michael Jeffreys for providing English translations of poems 20 and 24 with extensive annotations. Elizabeth and Michael Jeffreys discuss the so-called 'Manganeios Prodromos' and poems 20 and 24 in their 'The "Wild Beast from the West": Immediate Literary Reactions in Byzantium to the Second Crusade', in The Crusades from the Perspective of Byzantium and the Muslim World, ed. Angeliki E. Laiou and Roy Parviz Mottahedeh (Washington, D.C., 2001), pp. 101-16. For published extracts from poems 20 and 24, including some relevant discussion, see Emmanuel Miller in Recueil des Historiens des Croisades: Historiens grecs, 2 vols (Paris, 1875-81): 2: 188, 220-25, 228-29, 757-59. Paul Magdalino has listed the extensive corpus of Manganeios Prodromos in his The Empire of Manuel I Komnenos, pp. 494-500. 
demonstrated, verse encomia should be considered as sanctioned imperial media and tools of imperial propaganda. ${ }^{6}$

A malleable template provided the encomiasts with their essential fundamental themes and rhetorical methods of acclamation. The main preoccupation of the encomiasts was to extol the emperor's competitive deeds. These were divided into those of peace and war and addressed under the headings of the four imperial virtues: bravery, justice, temperance and wise prudence. To acclaim the emperor's virtues, a synkrisis, or a technique of comparing the current emperor with historical, biblical and mythical figures and previous emperors was commonly employed.

Additional themes could augment this laudatory formula, which in the earliest extant encomia produced during the initial years of Manuel Komnenos's unusual and controversial elevation to the imperial throne four years before the Second Crusade, very often reflected the emperor's inaugural propaganda. Manuel was the fourth and last-born son of John II Komnenos. The young Manuel had accompanied his father on campaign to Syria in 1142, and during their return a year later, John seems to have died in suspicious circumstances while hunting. Manuel hastened back to Constantinople to secure control of the empire against Isaac, his one surviving brother. Not only was the young Manuel's succession remarkable, it also departed from the conventional wisdom that the emperor should be a man of mature years, naturally imbued with the four imperial virtues. Manuel's inaugural propaganda, therefore, became the propaganda of legitimisation. The emperor is portrayed as a vigorous youth, and yet he is still imbued with an elder statesman's imperial virtues that legitimised his rule. This notion of an 'old head on young shoulders' provides one of many forms of contrast typical in the encomia. Such contrasts are employed in a process of rhetorical amplification whereby Manuel's theoretical virtues of bravery, philanthropy and wisdom are magnified by what are, in effect, apologias for the emperor's youth. In turn, the qualities of youth are thus themselves inflated by their obsequious comparison with imperial virtues. Accordingly, particular themes and motifs which augment the essential fundamental laudatory formula, and are common in all encomia, are stressed and repeated to unprecedented degrees in Manuel's inaugural propaganda. As we will be shown, the theme of Latin barbarism is prominent in the work of Manganeios Prodromos. The topos of the treacherous, stupid, arrogant, aggressive, anarchic and belligerent Latin barbarian is employed as a foil for native imperial virtue. ${ }^{7}$ It is worth noting that Paul Magdalino presumes the poems of Manganeios Prodromos exemplify those written during Manuel's early reign and that the extant verse encomia are only a fraction of those produced. ${ }^{8}$

Poems 20 and 24 concerning the Second Crusade and composed by Manganeios Prodromos exhibit the full gamut of the encomiast rhetorical conventions. Manganeios was in the service of Eirene, wife to the sebastokrator Andronikos (II), at the time of the crusade. The poems were therefore written and presumably performed by an eyewitness for eyewitnesses in Constantinople. Poem 20 was written within weeks of King Conrad III's crossing of the Bosphoros during the last days of September 1147. ${ }^{9}$ Poem 24 may have been written only days after the army headed by King Louis VII of France, which advanced on

\footnotetext{
${ }^{6}$ On verse encomia see Magdalino, The Empire of Manuel I Komnenos, pp. 413-88. Public speakers began to use encomia to lobby and advise during the course of the thirteenth century. See Dimiter Angelov, 'Byzantine Imperial Panegyric as Advice Literature (1204-c. 1350)', in Rhetoric in Byzantium, ed. Elizabeth Jeffreys (Aldershot, 2003), pp. 55-72.

${ }^{7}$ On the Latin barbarian topos, see Jason T. Roche, 'The Byzantine Conception of the Latin Barbarian', in Medieval Images of the Other in Scandinavia, Western Europe and Byzantium, ed. Kurt Villads Jensen, Janus Møller Jensen and Carsten Selch Jensen (Odense, forthcoming).

${ }^{8}$ Magdalino, The Empire of Manuel I Komnenos, pp. 348-49, 440-41.
} 
Constantinople in the wake of the German force, had commenced its march in Anatolia, 26 October $1147 .{ }^{10}$ Both poems were certainly written before news of the Germans' failure to get to the Seljuk capital of Ikonion had reached Constantinople.

Evidence that can be gleaned from the encomia of Manganeios Prodromos is echoed in the later Greek histories of the Second Crusade. This offers the tantalising suggestion that the one-time imperial secretaries John Kinnamos and Niketas Choniates used the encomiast's poems as sources of evidence. It may be that all three writers had access to a similar, if not the same, first-hand narrative of the events they purport to describe. This in turn may or may not have provided the basis for an official imperial notice, that is, a Byzantine version of the modern-day press release. Notwithstanding that editors of Manganeios Prodromos suggest that such a bulletin was employed by all three Greek sources,${ }^{11}$ corroborative echoes often exist between the verse encomia and narrative histories because the historians largely perceived past events and individuals through 'a thick, bright haze of rhetorical hyperbole' derived from encomia. ${ }^{12}$ This is particularly evident in Kinnamos, whose narrative can read like a historical representation of the information alluded to by Manuel's encomiasts. When comparing the Second Crusade narratives, and in particular that of John Kinnamos, with the rhetorical techniques, themes and motifs found in the poems of Manganeios Prodromos, it becomes evident that the Byzantine histories of the Second Crusade were profoundly shaped by encomiastic literary tradition, and should be interpreted accordingly.

John Kinnamos first notes the well-known disorder on the Second Crusade when he refers to the 'barbarians' ( $\beta \dot{\alpha} \rho \beta \alpha \rho o l)$ (read German crusaders) who began to seize market provisions without payment and put to the sword those who resisted as they advanced beyond Sardika. King Conrad of Germany was apparently heedless of what was happening, that is, he either paid no attention to those who advised him of the pillaging, or else he ascribed it to the wantonness of the mob. Kinnamos is here anticipating the contents of a letter hypothetically written by Conrad to the Byzantine emperor, which the historian records later in his chronicle. ${ }^{13}$ Odo of Deuil, chaplain to the King Louis VII of France on the Second Crusade, supports the evidence for German acts of pillaging as the crusaders initially advanced in Byzantine territory. Odo is likely to be correct in noting that it was because of German pillaging that the Greek agricultural producers and merchants took measures to protect themselves behind their town walls when selling the French crusaders their market wares. ${ }^{14}$

Odo's interpretation of his king's endeavour, however, rarely permits him to advance a comprehensive rational justification for the actions of the non-French encountered on

${ }^{9}$ Poem 20 refers only to German crusaders. As there is no reference to the French army, it was evidently written before King Louis VII of France arrived at Constantinople, 4 October 1147. On the French at Constantinople, see Wilhelm Bernhardi, Konrad III. (Leipzig, 1883), pp. 640-41.

${ }^{10}$ According to Odo of Deuil, the French army began its advance in Anatolia on the day of a solar eclipse, 26 October 1147: Odo of Deuil, De profectione Ludovici VII in orientem, p. 82. In Poem 24, which refers to both the French and German armies, Manganeios mentions the solar eclipse that occurred on the day a council of German princes decided to halt their advance on Ikonion and retreat to Nicaea. Manganeios takes apparent delight in Manuel's use of mercenaries against the army, as well as the death and starvation of crusaders outside Constantinople. However, there is no echo in the encomia of the German army's suffering and retreat in the deserts of Anatolia. This omission suggests that Manganeios's poems were composed before news of the retreat was received in the capital.

${ }^{11}$ Jeffreys and Jeffreys, 'The "Wild Beast from the West", p. 103, n. 7.

12 Magdalino, The Empire of Manuel I Komnenos, pp. 20-22, 413.

13 John Kinnamos, 'Epitome rerum ab Ioanne et Alexio Comnenis Gestarum', pp. 70-71 and Deeds of John and Manuel Comnenus, p. 61.

${ }^{14}$ Odo of Deuil, De profectione Ludovici VII in orientem, pp. 40-42. 
crusade. ${ }^{15}$ One example may serve to illustrate this point. In a passage of text that employs the furor Teutonicus negative ethnic stereotype, Odo goes into remarkable detail concerning the violence that erupted in a Latin settlement outside the city of Philippopolis. ${ }^{16}$ According to Odo, the violence was instigated by mad and impetuous drunken crusaders who foolishly presumed that a snake charmer entertaining in a tavern planned to poison them. ${ }^{17}$ It is instructive to compare Odo's rather cursory account of French indiscipline at Worms with his meticulous description of the German violence at Philippopolis. ${ }^{18}$ There is no need for Odo to locate a minor incident sparked off by a handful of irrational inebriates from within a host of many thousands to explain why violence erupted at Worms. He was fully aware that the French crusaders might have caused the disturbance when violently securing scarce provisions. Odo rarely allows the Germans such a rational explanation for their apparent actions.

The disorder outside Philippopolis does not appear to have provided contemporary encomiasts with enough material for them to apply the full gamut of stereotypical anti-Latin rhetorical disdain in their imperial propaganda. If it was widely believed that the disruption was simply the result of Latin aggression and idiocy, it is likely there would be an echo of it in contemporary verse encomia, and perhaps accordingly, the later Greek histories. As will be shown, the encomiasts, as represented by Manganeios Prodromos, and the Greek historians, particularly John Kinnamos, take every opportunity to disparage the perceived objectionable traits of the Latin barbarian. Those traits include the notion that Latins were inherently violent and stupid. There is no echo of the disorder outside Philippopolis in John Kinnamos's narrative. Manganeios Prodromos, who portrays the crusader army as a hostile force bent on conquering Byzantine territory, simply takes the opportunity provided by the clash to deride a proud, arrogant and boastful King Conrad. The king apparently lacked calculation and was too 'confident in his weight of numbers'. ${ }^{19}$ Thus, because of stereotypical Latin arrogance, which led the crusaders to discount any threat from the native Byzantines, the inhabitants of Philippopolis worsted the crusaders. The crusader defeat then allows Manganeios Prodromos to evoke an encomiastic theme which played on the emperor's name, that is, the emperor's eponymic comparison with Christ Emmanuel. The comparison was employed to legitimise the pious emperor's unexpected, yet divine succession to the imperial throne. ${ }^{20}$ Accordingly, God and Manuel 'named for Christ, but for one syllable', 'he who brings down the pride of the haughty / unexpectedly broke his [Conrad's] boldness'. ${ }^{22}$

15 This argument and other new interpretations of Odo of Deuil's testimony were was first put forward in Jason T. Roche, 'Conrad III and the Second Crusade in the Byzantine Empire and Anatolia, 1147' (Unpublished $\mathrm{Ph} . D$. thesis, University of St. Andrews, 2008), pp. 47-93. In a recent misrepresentation of Roche’s work, Conor Kostick implies that Roche rejects all of Odo of Deuil's evidence of German indiscipline. This is far from the case. Roche argues that nuances in many of Odo's anecdotes leave a distorted impression that the Germans conducted themselves significantly worse that their fellow French crusaders. See Conor Kostick, 'Social Unrest and the Failure of Conrad III's March through Anatolia, 1147', German History 28 (2010), 125-42 (here 13233).

${ }^{16}$ Lucan's phrase 'furor Teutonicus' translates literally as the 'fury of the Germans'. However, the word furor has connotations of impetuosity, irrationality and indeed, madness. Ernst Dümmler was the first to note instances of the negative ethnic stereotype appearing in Odo's letter; see his 'Über den Furor Teutonicus', Sitzungsberichte der preussischen Akademie der Wissenschaften, phil.-hist. Klasse (Berlin, 1897), pp. 112-26.

${ }^{17}$ Odo of Deuil, De profectione Ludovici VII in orientem, pp. 40-42.

18 Odo of Deuil, De profectione Ludovici VII in orientem, pp. 22-23.

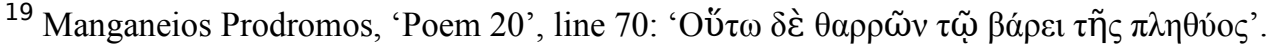

20 See Magdalino, The Empire of Manuel I Komnenos, pp. 434, 449.

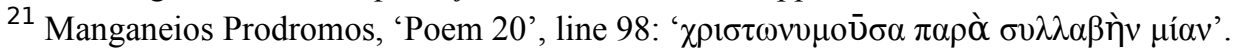


Gleaning through the Latin barbarian topoi, allusions to Homeric verse and other encomiastic rhetoric in Niketas Choniates's work reveals another version of the events at Philippopolis. Conrad III is said to have enjoyed the hospitality of the metropolitan of the city, Michael Italikos, while refusing to pay for grain that was brought to him. Unspecified forms of violence erupted between the crusaders and Byzantines once Conrad had advanced ahead with the vanguard. Employing pejorative animal imagery to intimate the non-Greek's lack of humanity, indeed his barbarity, Choniates next has a wild and bestial Conrad turning back toward Philippopolis with the intention of joining in the fray. ${ }^{23}$

There are thus three rather different versions of the events outside Philippopolis. Odo of Deuil's unsubstantiated tale of the trouble is rather fanciful; Manganeios Prodromos uses the clash in furtherance of imperial propaganda; and both of these authors, like Niketas Choniates after them, rely on negative ethnic stereotypes to inform their respective audiences. Notwithstanding that there clearly was a disturbance outside Philippopolis and that some of the crusaders seem to have suffered at the hands of soldiers stationed in the city, one would be ill advised to try to ascertain the reason for, and scale of the fracas by a straightforward reading of the problematic evidence. ${ }^{24}$

While recuperating from an illness in a monastery near Adrianople, the next major centre of habitation en route to Constantinople, a German nobleman was murdered by what Choniates calls ruthless Romans ${ }^{25}$ and Kinnamos designates as foot soldiers. King Conrad's nephew, Duke Frederick of Swabia, described by Kinnamos as an ungovernable warlike man and by Choniates as being warlike by nature subsequently turned back from the advance towards Constantinople. Frederick then set fire to the monastery where his fellow crusader had perished and killed the supposed perpetrators. ${ }^{26}$ The identity of the murdered nobleman remains unknown. Choniates suggests that he was a kinsman of Conrad III and therefore a relative of Frederick of Swabia, better known to history as Frederick Barbarossa. Choniates recognised that the nobleman's murder was likely to lead to a Latin act of noble retribution. He even states that the king instructed his nephew to seek revenge for the killing. Conor Kostick's recent discussion of this episode betrays the continued influence of the historiographical convention established by Kugler in the nineteenth century. ${ }^{27}$ Kostick argues that this incident demonstrates that the king had difficulty controlling even his most senior nobles. He also advances the incident as an example of the 'unsanctioned actions' of the supposedly extraordinarily disorderly Germans. ${ }^{28} \mathrm{~A}$ careful reading of arguably the most balanced of the sources referring to this particular episode suggests something quite different. To Choniates, ruthless Romans murdered a sick man in a monastery, and unexceptionally,

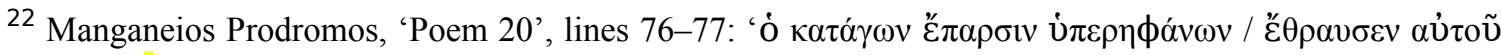

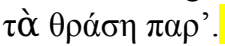

${ }^{23}$ Niketas Choniates, Nicetae Choniatae Historia, 1: 62-63 and O City of Byzantium, p. 37. Choniates follows the rhetorical conventions of the ancient Greek tragedians here in depicting the barbarian Conrad as beastial. See Roche, 'The Byzantine Conception of the Latin Barbarian'.

${ }^{24}$ Compare with Kostick, 'Social Unrest and the Failure of Conrad III's March through Anatolia, 1147', p. 132.

25 The Byzantines professed to be Rhomaioi, that is, (descendants of) Romans.

26 Niketas Choniates, Nicetae Choniatae Historia, 1: 63-64 and O City of Byzantium, p. 37; John Kinnamos, 'Epitome rerum ab Ioanne et Alexio Comnenis Gestarum', p. 71 and Deeds of John and Manuel Comnenus, p. 61.

27 See note 4 above.

${ }^{28}$ Conor Kostick, 'Social Unrest and the Failure of Conrad III’s March through Anatolia, 1147’, p. 131.
} 
Conrad actually instructed one of his most senior nobles, Duke Frederick of Swabia, to avenge his relative's death. ${ }^{29}$

Choniates simply states that this incident became the cause of some conflict which Prosouch, a seasoned commander charged with curtailing the crusaders' plundering and pillaging activities, settled relatively easily ${ }^{30}$ But Kinnamos suggests Prosouch 'made a great slaughter of the barbarians' and from then on the 'Germans abandoned their prior boasting, having been taught the Romans' might'. ${ }^{11}$ Similarly, Manganeios Prodromos writes that:

from the corpses lying slaughtered nearby,

Adrianople made him [Conrad] understand, too late,

that he would be joining battle with men of great exploits,

whose bows are of bronze and whose arm is of iron,

or rather those supported by the breaker of boldness,

God's own arm, his son and Word,

supporting their arms by his strength. ${ }^{32}$

The differences between Choniates's narrative here and those of Kinnamos and Manganeios may reflect an attempt by Choniates to contradict imperial propaganda and the concomitant image of the emperor both represented in verse encomia. ${ }^{33}$ To Choniates, writing at the beginning of the thirteenth century, the Latins of the West appeared to have received God's favour to the detriment of the Greeks. He may have chosen to omit the apparent Byzantine success against the crusaders, and preferred to stress instead the apparent 'sinful' acts of Byzantines against the Latin barbarians. ${ }^{34}$ Choniates's worldview probably induced the historian to praise Barbarossa's piety and devotion when recounting the death of the then Holy Roman emperor on crusade in $1190 .{ }^{35}$ Concerning the events near Adrianople in 1147 , Choniates certainly attempts to offer a reason for Barbarossa's actions beyond attributing them to the stereotypical traits of the Latin barbarian as usually expressed in contemporary Greek rhetoric.

Conversely, it is implicit in the work of Kinnamos and Manganeios that the barbarian Barbarossa is worsted near Adrianople by the Byzantines because they are martially and spiritually superior to the undisciplined, arrogant crusaders. It would be remiss to accept a literal reading of the Greek sources. The supposed martial prowess of Byzantine troops, or rather, the 'Romans' might', and by extension that of the emperor Manuel Komnenos, is a familiar encomiast theme maintained throughout Manuel's reign. ${ }^{36}$ The disturbance at Adrianople evidently provided verse encomiasts such as Manganeios Prodromos with enough dramatic material to enable them to weave a suitable panegyric. It will be remembered that the poets used a process of rhetorical amplification to magnify the significance of events and

${ }^{29}$ Niketas Choniates, Nicetae Choniatae Historia, 1: 63-64 and O City of Byzantium, p. 37.

${ }^{30}$ Niketas Choniates, Nicetae Choniatae Historia, 1: 64 and O City of Byzantium, p. 37.

31 John Kinnamos, 'Epitome rerum ab Ioanne et Alexio Comnenis Gestarum', pp. 71-72 and Deeds of

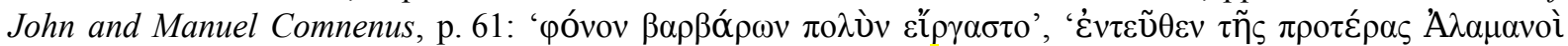

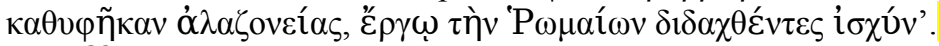

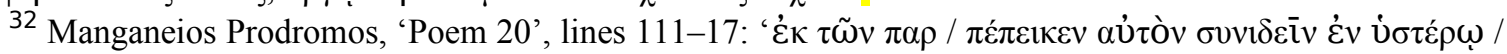

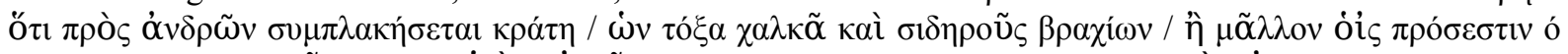

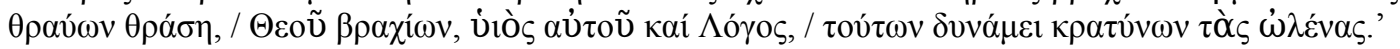

33 Cf. Magdalino, The Empire of Manuel I Komnenos, pp. 478-83.

34 On Choniates's perception of divine providence, see Magdalino, The Empire of Manuel I Komnenos, pp. $14-15,18-20$.

${ }^{35}$ Niketas Choniates, O City of Byzantium, pp. 228-29.

${ }^{36}$ See Magdalino, The Empire of Manuel I Komnenos, p. 467. 
occurrences the better to reflect the achievements of those being eulogised. ${ }^{37}$ It is therefore very likely that the encomiasts exaggerated the severity of the disturbance at Adrianople the better to inflate the skill and expertise of Manuel and his commanders in defeating the barbarians. Although it is not certain that Kinnamos and Choniates employed verse encomia as evidence for their portrayal of events at Adrianople, the historians habitually utilised such sources and there are unquestionably echoes of the encomiastic tradition in Kinnamos's narrative. If the encomiasts employed a process of rhetorical amplification to magnify the Byzantines' success in defeating the intrinsically violent Barbarossa, and if Kinnamos and Choniates did utilise encomia as sources for interpreting this event, the authors would understandably have perceived it as a significant occurrence rather than an inconsequential event that nonetheless facilitated the encomiasts' agenda. It is perhaps telling that this incident does not appear in any of the Latin sources. The Latin texts admittedly provide little detail on this part of the crusaders' advance, although the flash flood on the plain of Choirobacchoi received considerable attention in a number of excellent Latin sources. ${ }^{38}$ This suggests that, unlike the flash flood, the Latin sources did not consider the confrontation at Adrianople significant enough to repeat or record. There is one last thing to consider: the Greek perception of the Latin West and the concomitant canon of rhetorical topoi employed to describe and explain Latin behaviour ensure that clashes between the 'barbarians' and 'Romans' are unlikely to be portrayed in any other manner. Modern scholars would not expect the panegyrist Manganeios Prodromos to offer them rational explanations for why Barbarossa returned to Adrianople, or indeed, why he was seemingly worsted by Prosouch. John Kinnamos likewise had no need to offer an explanation: the Byzantine reader and listener understood that Barbarossa was an undisciplined belligerent barbarian, and that as such his actions were only to be expected.

Clearly, caution must be exercised before accepting Greek portrayals of crusader activities which might be subject to encomiastic exaggeration and that are not found in the Latin texts. Just as importantly, the crusaders are almost inevitably depicted as bellicose, supercilious barbarians, which manifestly could distort the Greek sources. A case in point is Kinnamos's statement that even after Barbarossa's defeat near Adrianople, the crusaders were

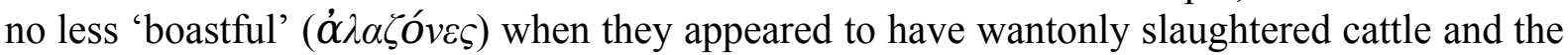
farmers who resisted them. ${ }^{39}$ This incident is interesting because the narrative shows how Byzantine rhetoric can conceal fundamental realities regarding the passage of large medieval armies. It was often imperative for an army to live off the land it traversed (and Byzantine armies were no exception ${ }^{40}$ ), but Kinnamos ascribes the crusaders' pillaging here to the Latins' stereotypical traits.

Sometime after the crusaders had advanced from Adrianople, a Byzantine representative advised the German princes to advance into Asia Minor via the ferry crossing at Abydos. At a council meeting convened to discuss the proposal, the princes agreed to continue on the road to Constantinople. According to Kinnamos, Manuel then dispatched the military commander, Basileios Goudelios Tzikandyles, to reinforce Prosouch; they had

37 See Magdalino, The Empire of Manuel I Komnenos, p. 421.

${ }^{38}$ Otto of Freising, Gesta Frederici, I.48 (pp. 218-23) and The Deeds of Frederick Barbarossa, pp. 80-81; Helmold of Bosau, 'Chronica Slavorum', I.65 (pp. 218-19); 'Annales Herbipolenses', p. 4; Gerhoh of Reichersberg, 'De investigatione Antichristi', p. 374; Odo of Deuil, De profectione Ludovici VII in orientem, pp. $46-48$

39 John Kinnamos, 'Epitome rerum ab Ioanne et Alexio Comnenis Gestarum', p. 72 and Deeds of John and Manuel Comnenus, p. 62.

40 John Haldon, Warfare, State, and Society in the Byzantine World, 565-1204 (London, 1999), pp. 13954, 166-76, 239-52. 
instructions to engage the advancing Germans should they commence 'unjust violence' $(\chi \varepsilon \imath \rho \tilde{\omega} v \dot{\alpha} \delta \dot{\imath} \kappa \omega v)$. Prosouch and Tzikandyles apparently spied on the fully armoured Germans and 'perceived that their physiques were excessively large'. They also noted that the crusaders' marching column was disordered, and thought they would be easily overcome by Romans who engaged them with military science. This they duly reported to Manuel. The emperor is said to have remained cautious because of the barbarians' ostensible purpose of travelling to the Holy Land, and that he shrank from attacking them until they engaged in unjust aggression. ${ }^{41}$

Kinnamos peppers his narrative here with encomiastic rhetoric. Perhaps the most obvious example is the reference to the physical size of the fully armoured Germans, an observation found in Manganeios who writes of the Germans donning armour and 'becoming immediately iron-clad giants'. ${ }^{42}$ Less obvious are the key encomiastic themes that Kinnamos employs. The notion that the emperor's acts of violence against unjust aggression (such as crusader pillaging) constituted 'just war' was part of the celebration of Comnenian militarism. ${ }^{43}$ This became highly developed in the encomia which were produced during the reigns of the Komnenoi. The imperial family were, of course, members of the military aristocracy. The celebration eulogised the martial efficacy of the imperial subjects and, by extension, that of the emperor himself. ${ }^{44}$ In Kinnamos's narration, Comnenian military science, an encomiastic phrase seemingly employed to accentuate the martial skill of the emperor and his commanders would easily overcome the excessively large barbarians. This was entirely natural: the crusaders did not employ military science and exercised disorder on the march instead. Again, in contrast, a pious, temperate and judicious emperor, that is, an emperor imbued with fundamental imperial virtues celebrated in the encomia, was disinclined to engage the crusaders - even though they were undisciplined - because of their ostensible purpose of marching to the Holy Land.

The rhetoric of the encomiasts is evident in the historians' descriptions of the flash flood on the plain of Choirobacchoi which the crusaders reached on 7 September 1147. A night storm caused the plain's rivers to rise rapidly, and the resulting deluge struck the crusader camp leading to the loss of many people, beasts and baggage. ${ }^{45}$ Manganeios tells of the flood with apparent glee. He compares Conrad to Pharaoh and the flood to the Red Sea. The divine flood, which Manganeios portrays as halting Conrad's plans to attack the Byzantine forces sent to shadow the Germans' movements, is actually presented as surpassing the biblical model. In 1147, he says, water appeared where there was once only dry land: 'Thus were the plans of the godless scattered by Him / who easily changes everything to His will' ${ }^{46}$ The flash flood, which Manganeios states had not happened since antiquity, enraged the 'wild boars' (read 'crusaders'), who were less rational than the biblical Gadarene swine.

\footnotetext{
${ }^{41}$ John Kinnamos, 'Epitome rerum ab Ioanne et Alexio Comnenis Gestarum', p. 72 and Deeds of John

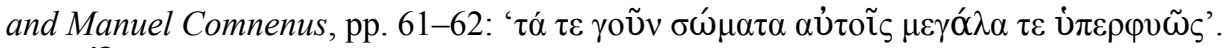

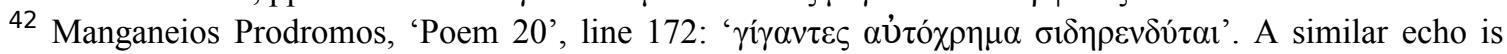
found in Niketas Choniates who refers to the huge stature of the German crusaders: Niketas Choniates, Nicetae Choniatae Historia, 1: 64 and $O$ City of Byzantium, p. 38.

43 The article employs the familiar adjective Comnenian throughout.

44 See Magdalino, The Empire of Manuel I Komnenos, pp. 419-21, 467.

45 Otto of Freising, Gesta Frederici, I.43 (pp. 218-23) and The Deeds of Frederick Barbarossa, pp. 80-81; Helmold of Bosau, 'Chronica Slavorum', I.65 (pp. 218-19); 'Annales Herbipolenses', p. 4; Gerhoh of Reichersberg, 'De investigatione Antichristi', p. 374; Odo of Deuil, De profectione Ludovici VII in orientem, pp. 46-48.

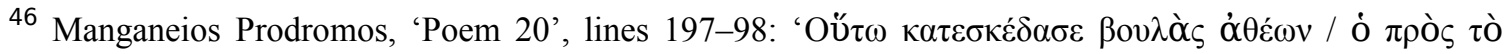

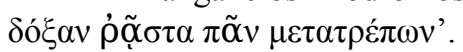


In contrast, Manganeios compares a youthful Manuel to the 'white-haired intelligence' of Daniel, 'first of the elders to whom the Lord of all gave the power'. He also praises the emperor's 'natural ideas of the good' when he elucidates how Christ and the Virgin had come to Manuel's aid. ${ }^{47}$

John Kinnamos likewise gives the impression that the flood was a disaster beyond description and his portrayal of the deluge shares several details with those provided by Manganeios. Most importantly, Kinnamos also states that the flood was an act of divine retribution. Such interpretations are not especially common in the work of Kinnamos, and perhaps reflect his employment of encomiastic material with its heavy use of biblical themes. $^{48}$

Niketas Choniates's description of the flood is also similar to that given by Manganeios. Choniates states that those who witnessed the event concluded that God's wrath had fallen on the German camp, which again, may or may not be an echo of contemporary encomia. Unlike Manganeios and Kinnamos, Choniates does not suggest why God may have intervened in the crusaders' advance. In fact he points out the flood was an annual event, rather than a unique act of providence. This act of apparent censorship of Byzantine opinions and imagery, which prevailed in the mid-twelfth century, may again reflect Choniates's interpretation of divine providence. It may also reveal an attempt to alter the received rhetorical representation of this event. Accordingly, the flash flood was an annual occurrence and not an act of divine intervention on behalf of God's people and their emperor, Manuel; the Latins had become His chosen subjects. Conrad was nonetheless still a barbarian. The historian employs the rhetorical barbarian topos when he states that the king thereafter set aside his innate petty arrogance and peacefully continued his advance towards Constantinople. ${ }^{49}$

Manuel's preparations for receiving the army at his capital included strengthening the garrison. ${ }^{50}$ The emperor also made repairs to the city walls. Poem 24 from the corpus of Manganeios Prodromos is a panegyric delivered in the persona of the capital. It eulogises the emperor's success in driving off the armies of the Second Crusade, which, as has already been noted, Manganeios portrays as hostile invading forces. In doing so, the encomiast evokes pejorative animal imagery to reflect the supposed barbarity of the non-Byzantines. He writes that,

the wild beasts had heard that my teeth had fallen out, and came to hunt and devour me.

But, like Christ Emmanuel, the young Manuel

showed that I, the old woman, am young, with all my teeth.

And the wild beast is afraid of my teeth's fresh growth. ${ }^{51}$

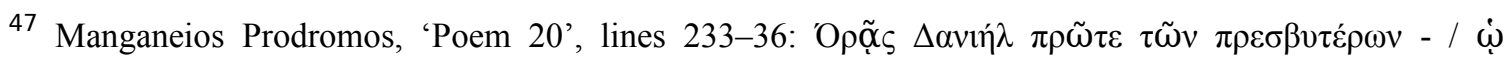

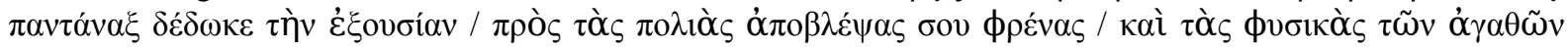

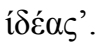

48 John Kinnamos, 'Epitome rerum ab Ioanne et Alexio Comnenis Gestarum', pp. 73-74 and Deeds of John and Manuel Comnenus, p. 63.

${ }^{49}$ Niketas Choniates, Nicetae Choniatae Historia, 1: 64-65 and O City of Byzantium, pp. 37-38.

50 John Kinnamos, 'Epitome rerum ab Ioanne et Alexio Comnenis Gestarum', p. 72 and Deeds of John and Manuel Comnenus, p. 62; Niketas Choniates, Nicetae Choniatae Historia, 1: 62 and O City of Byzantium, p. 36.

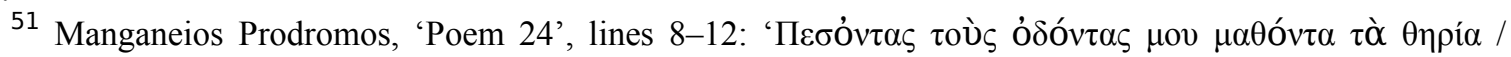

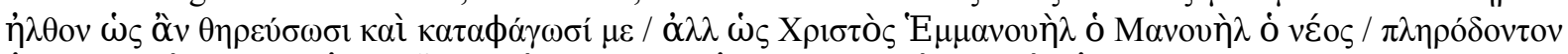

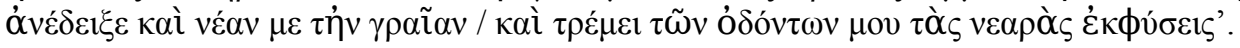


This apparent allusion to the repair of the city's fortifications finds a corroborative echo with Choniates; he confirms that Manuel did indeed repair the walls and battlements, that is, the city's 'teeth', upon approach of the crusaders. ${ }^{52}$ Odo of Deuil, who stated that part of the city walls collapsed in front of the French army, betrays the embellishment of Manuel's achievements inherent in the encomia of the period. ${ }^{53}$

A number of other Greek texts demonstrate that the crusade was perceived as a threat to Byzantine security. A letter and accompanying political verse commentary written by the contemporary John Tzetzes concerning the oracle 'an ox will bellow and a bull will wail' shows that the approach of the German army was associated with the prophesied destruction of Constantinople. ${ }^{54}$ Manganeios Prodromos declared that the crusaders were more numerous than the stars. ${ }^{55}$ An encomium composed in $1152-53$ by Michael the Rhetor describes the numbers of crusaders as comparable to sand on the seashore. He writes that a myriad host was drawn up for battle and violently sweeping everything before it, like a river in flood. ${ }^{56} \mathrm{An}$ encomium delivered in 1174 by Eustathios of Thessalonica describes the crusaders boiling up from the west and attacking the Byzantines without provocation. ${ }^{57}$

Manganeios describes Conrad of Germany's crusade as a ruse; the king's real intention was to conquer Byzantine territory and impose a Latin patriarch in Constantinople. The king thus exhibits the hypocrisy of a fox and wears 'on the outside a sheep's fleece but / concealing within a destructive wolf'. He is therefore a chameleon who secretly hides his designs for barbarian ambushes (witness the continued use of pejorative animal imagery). ${ }^{58}$ Manganeios insists that Conrad's army marched 'against our new Jerusalem', Conrad, 'this Sennacherib and new Doeg', ${ }^{59}$ 'this second Rabshakeh, worse than the first' ${ }^{60}$ Conrad was like Herodotus's Cyrus and 'not yet sated with bloodshed / and sought to be excessively intoxicated with it'. Manganeios hoped that Conrad would:

share in the condemnation of Cyrus

which Tomyris the Scythian queen adjudged,

justly throwing his head into a skin

which had been filled with blood,

crying 'Take your fill of blood, Cyrus',

52 Niketas Choniates, Nicetae Choniatae Historia, 1: 62 and O City of Byzantium, p. 36.

53 Odo of Deuil, De profectione Ludovici VII in orientem, p. 68.

54 John Tzetzes, Ioannis Tzetzae Epistulae, ed. P. Leone (Leipzig, 1972), pp. 87-88; John Tzetzes, Ioannis Tzetzae Historiae, ed. P. Leone (Naples, 1968), no. 9, pp. 611-12. On such prophecies, see Paul Magdalino, 'Prophecies on the Fall of Constantinople', in Urbs Capta: The Fourth Crusade and its Consequences, ed. Angeliki E. Laiou (Paris, 2005), pp. 41-54.

55 Manganeios Prodromos, 'Poem 24', lines 53-54.

56 Michael the Rhetor, 'Oratio ad Manuelem Imperatorem' ed. W. Regel, in Fontes Rerum Byzantinarum, Fasciculi 1 et 2: Rhetorum Saeculi XII Orationes Politicae, ed. W. Regel (St Petersburg, 18921917), p. 173.

57 Eusthathios of Thessalonica, 'Orationes' ed. W. Regel and N. Novossadsky, in Fontes Rerum Byzantinarum, pp. 105-6.

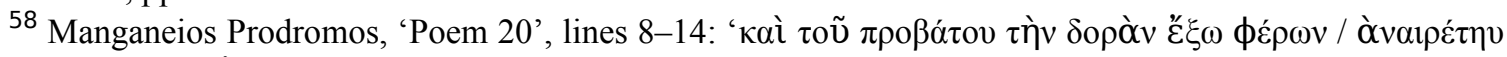

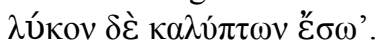

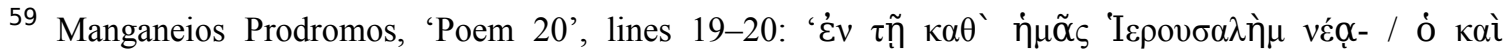

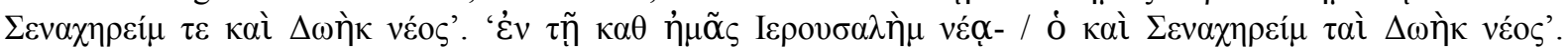
Sennacherib was a king of Assyria who attacked Judaea: Hezekiah 1.44. Doeg was the chief of Saul's herdsmen responsible for the murder of 85 priests suspected of taking David's (for David, read Manuel) side against Saul. Samuel 1.21-22.

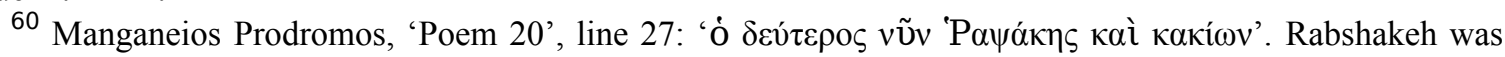
Sennacherib's messenger to Hezekiah and the Jews. Kings 2.18-19, Isaiah 36-37. 
correctly aiming at the insatiable blood letter

this saying, just like an arrow.

Witness the encomiastic technique of synkrisis or comparison with, in this case, despised mythical and biblical figures. The modern historian is presented with an image familiar to the Byzantines of belligerent, bloodthirsty barbarians bent on conquering Constantinople. ${ }^{61}$

John Kinnamos repeats this traditional notion. He likewise states that the crusade was merely a façade for Conrad's real intention, which was to take possession of Byzantine territory. ${ }^{62}$ There is also an echo of the encomia in Niketas Choniates here, and particularly noticeable is his use of animal imagery. He writes that Manuel was suspicious of the crusaders' intentions lest they were 'wolves coming in sheeps' clothing', which is clearly the same metaphor as that employed by Manganeios. Manuel had apparently described the crusaders as men with fire in their eyes, desirous of murder, and who exulted 'in the spilling of blood'. This is again reminiscent of Manganeios and his reference to the murderous Cyrus. However, Choniates states that the crusaders' claim to be marching to Jerusalem was not false. Narrating within the confines of Byzantine rhetorical convention evidently did not preclude such opinions. It seems again that Choniates is offering a corrective to the received understanding in the capital; namely, that Conrad's aim was not to conquer Byzantium as contemporary authors seemed to believe, or at least, would have their audience believe. ${ }^{63}$

Conrad reached the palace and park complex called the Philopation, opposite the palace of Blachernae and close to Constantinople's Golden Gate, around 9 September $1147 .{ }^{64}$ From here, he is said to have observed that the walls of Constantinople were impregnable. He thus resolved to cross the bridge over the Golden Horn and set up camp in the suburb of Pikridion. Kinnamos does not offer an opinion on why Conrad made this move. Given his apparent perception that Conrad headed a hostile army, perhaps Kinnamos believed that Conrad viewed the walls and rejected a frontal assault. ${ }^{65}$ Such a notion appears to have circulated in Constantinople at the time - perhaps propagated by the encomiasts. In poem 20, Manganeios Prodromos states that Conrad observed the walls from Pikridion and that he was passionate for his previous purpose, namely, the seizure of the city. Thus, 'he was inwardly convulsed, roaring like a wild beast', but Manuel,

foreshadowing in ways which imitate Christ, the face of the Lord, the prototype, you, whose name is like Christ's and are naturally meek, refusing to stain your hands with blood, you acquiesced in the swelling of a wild impulse

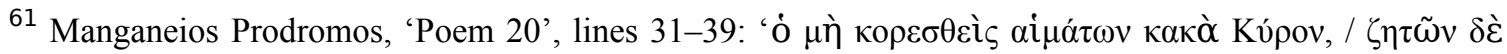

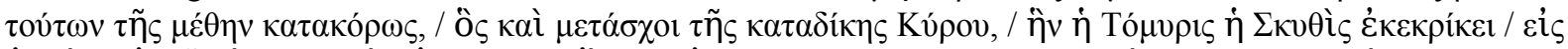

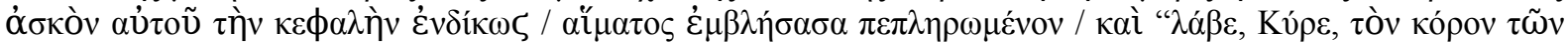

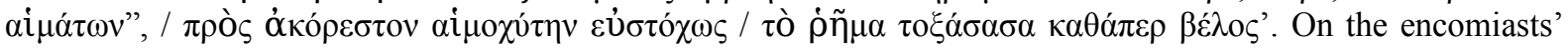
use of synkrisis see Magdalino, The Empire of Manuel I Komnenos, pp. 447-49, 452.

62 John Kinnamos, 'Epitome rerum ab Ioanne et Alexio Comnenis Gestarum', p. 67 and Deeds of John and Manuel Comnenus, p. 58.

63 Niketas Choniates, Nicetae Choniatae Historia, 1: 61-62 and O City of Byzantium, pp. 35-36: 'غ่v

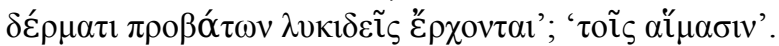

${ }^{64}$ Otto of Freising, Gesta Frederici, I.48 (pp. 218-23) and The Deeds of Frederick Barbarossa, pp. 80-81; 'Annales Herbipolenses', p. 4; Odo of Deuil, De profectione Ludovici VII in orientem, p. 48; Bernhardi, Konrad III., p. 614.

65 John Kinnamos, 'Epitome rerum ab Ioanne et Alexio Comnenis Gestarum', pp. 74-75 and Deeds of John and Manuel Comnenus, pp. 63-64; Choniates also mentions Pikridion. See Niketas Choniates, Nicetae Choniatae Historia, 1: 65-66 and O City of Byzantium, p. 38. 
and endured the beast's savagery,

though you yourself had a sword at your side,

though your heart too was boiling courageously:

for you were a disciple of the Lord of Peace. ${ }^{66}$

Witness the encomiastic motifs and themes we have seen already, namely, the crusaders as beasts and Manuel's eponymic association with Christ Emmanuel. In frequently making the latter comparison, the encomiasts endeavoured to create an image of the emperor as the ideal Christian ruler, comparable to the prototype, and thus divinely ordained to rule. This ideal promoted comparisons with biblical paradigms of kingship, notably those of David and Solomon. Manganeios proclaims that unlike Conrad, the inherently unrestrained and belligerent western barbarian, Manuel is naturally meek. He is therefore comparable to the peaceful David, youngest of the sons of Jesse, whom God also endowed with kingly power. Indeed, throughout Manuel's inaugural propaganda, he becomes a symbol of Davidic virtue par excellence and so worthy of his elevation to the imperial throne. ${ }^{67}$ The propaganda of legitimisation then continues with an apologia of the emperor's youth. Manganeios declares that - in stark contrast to the barbarian King Conrad - Manuel is in command of his passions even if he is boiling courageously with youthful aggression. Manganeios thus accentuates Manuel's temperate Davidic virtues and emphasises the legitimacy of Manuel's rule in spite of the emperor's youth, courage and the fact that he was the last-born son of his father ${ }^{68}$ But Manganeios continues, since Conrad,

was unable to hide the madness of his nature,

[he] openly rushed against the fold

to sacrifice the sheep and their shepherds

and to rend every lamb with his teeth. ${ }^{69}$

Manganeios presents Conrad as not only intent on besieging Constantinople, but as openly attacking the city. Manuel therefore set his 'guard-dogs against him to defeat the wolf / and the king is shattered and lowers his pride', ${ }^{70}$ and,

he who before was inflexible crossed to Damalis,

totally subdued, like a wolf among hounds,

the Scythian dogs who had met him. ${ }^{71}$

Pejorative animal imagery is employed again to illustrate the wild, uncultivated barbarism of the Latin crusader. By his very reckless nature, Conrad rushed to attack the 'Scythian dogs', that is, the Byzantine mercenaries who were neither Greek nor Orthodox Christian, and

66 Manganeios Prodromos, 'Poem 24', lines 14-50 and 'Poem 20', lines 310-20: 'ع̌ $\sigma \omega \theta \varepsilon v$ فंs $\theta \grave{\eta} \rho$

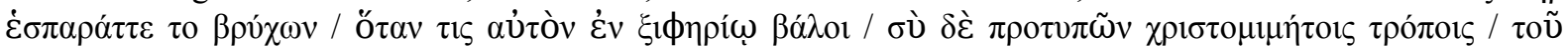

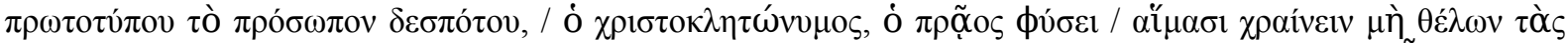

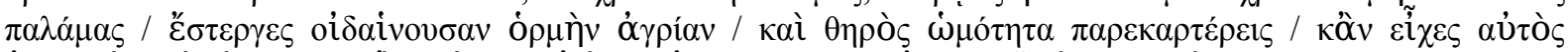

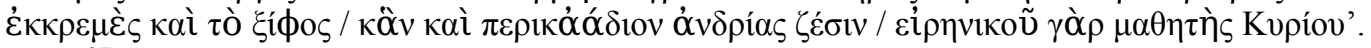

${ }^{67}$ Magdalino, The Empire of Manuel I Komnenos, pp. 416, 436, 447-48. Also see Manganeios Prodromos, 'Poem 20', lines 355-77.

68 Cf. Magdalino, The Empire of Manuel I Komnenos, pp. 434-37.

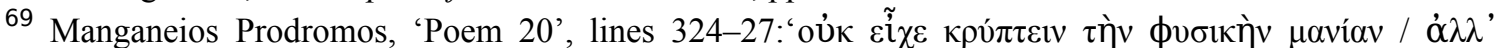

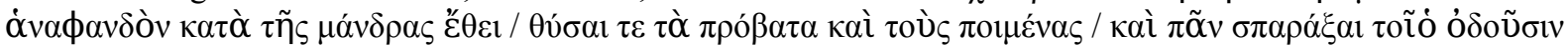
ápvíov'.

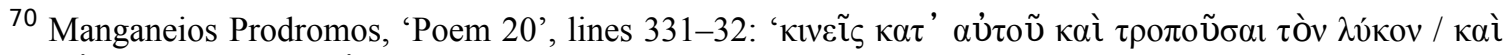

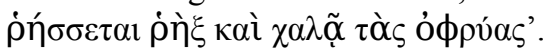

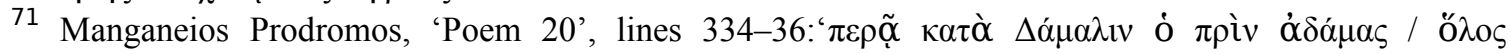

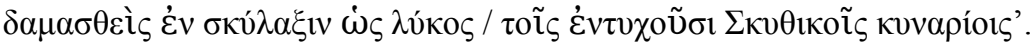


likewise, barbarian animals. According to Manganeios, Conrad's assault on the city and the mercenaries failed, and the army was compelled to cross over the Bosphoros to the suburb of Damalis.

Latin sources do not record the skirmish at Pikridion, suggesting that the survivors of the crusade were either unaware of the clash or perhaps that they deemed it unworthy of reporting. History, of course, does not agree that Conrad attempted to besiege Constantinople or attack the city, and the poems of Manganeios should not be accepted as evidence that he did so. The clash provided the encomiasts with suitably dramatic subject matter to perform their art and eulogise the emperor. In order to illustrate Manuel's legitimacy to rule, the encomiast employs rhetorical amplification that embroiders the skirmish at Pikridion into a major Comnenian success against the intrinsically violent barbarians. 'For', Manganeios applauds,
in just one engagement you destroy
the innumerable army with your tiny detachment, and with a small number of archers you show
that great man as a cowardly, trembling runaway. ${ }^{72}$

'Such are the triumphs of the imperial maiden / and the stratagems of the emperor', writes Manganeios. $^{73}$ In contemporary encomia, the imperial maiden is the capital herself. Manganeios continues by stating that the triumph of removing the crusaders from outside the city's walls belongs to the virtuous Manuel personally and not to the city. ${ }^{74}$

The rest of poem 20 and virtually the whole of poem 24 are eulogies of Manuel's virtues, and these, in turn, provide us with an illustration of the emperor's inaugural propaganda. An important aspect of the remaining rhetoric, which became commonplace during Manuel's reign, is a synkrisis of Manuel with his father John II, and his grandfather, Alexios I. Through the process of rhetorical amplification, Manuel's early dealings with the principality of Antioch and the Second Crusade were presented as surpassing his father's efforts in Cilicia and northern Syria, and his grandfather's handling of the First Crusade. ${ }^{75}$ In poem 24, for example, Manganeios declares to Manuel that:
you yourself supplied your ancestors' deficiencies, and became the culmination of your father's and grandfather's glory.
Of those previous emperors, the roots of your might, one defeated the Latins by engaging them here, the other later, after an expedition against Antiochos' city. But they, in wreathing their crowns of victory, both your grandfather and your father left them half-finished. ${ }^{76}$

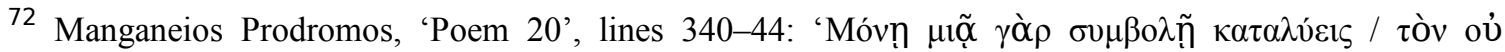

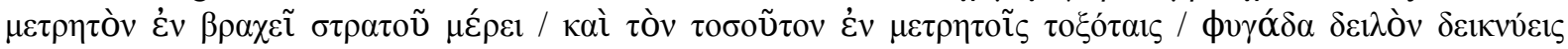
$\tau \rho о \mu \alpha \lambda \varepsilon ́ o v '$.

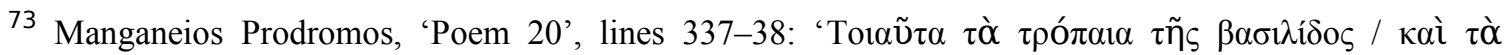

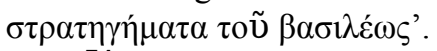

${ }^{74}$ Manganeios Prodromos, 'Poem 20', line 349.

${ }^{75}$ Magdalino, The Empire of Manuel I Komnenos, p. 448. See also Paul Magdalino, 'The Pen of the Aunt: Echoes of the Mid-Twelfth Century in the Alexiad', in Anna Komnene and Her Times, ed. Thaila GoumaPeterson (New York, 2000), pp. 15-43.

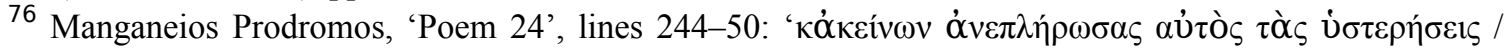

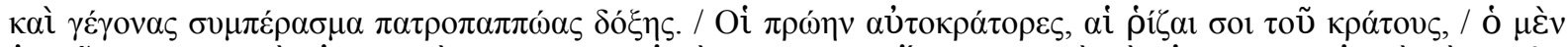

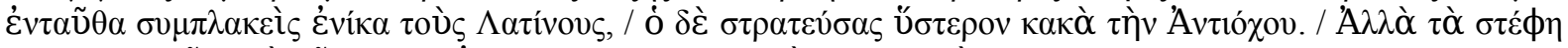

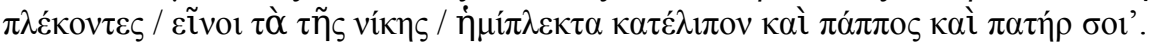


Manuel, however,

defeated the great kings here, and as for the dragon ruler of Antioch, you made him scrabble around like a little puppy at your majesty's crimson-shod feet [...]

For their half-finished victories against the Latins have been completely rounded out by your total victory; and to their crowns and glories you have added a much more brilliant crown and glory. ${ }^{77}$

The process of rhetorical amplification, which is endemic in the verse encomia, is plainly evident. Alexios's defeat of the Latins 'here' actually entailed negotiating the relatively peaceful passage of the First Crusade through Constantinople. John's victory must relate to one of the impressive but largely ineffectual expeditions against Antioch in 1137 and 1142 . The outcomes of these events are themselves exaggerated. This process then naturally inflates Manuel's portrayed defeat of the besieging 'kings' (which is shorthand in the encomia for the Second Crusade) at Pikridion. The process also inflates the success of the combined expedition by land and sea to Antioch in 1144; a campaign that culminated a year later when the 'dragon' prince of Antioch, Raymond of Poitiers, paid homage to Manuel in Constantinople. $^{78}$

The rhetorical comparison of the Latin barbarians to a violent uncontrollable force of nature is another important feature of the encomia. Manganeios writes of:

The wild uprising and attack of the sea,

rushings, tossings, boilings and all other kinds of violence,

gales, waves, rough seas and storm,

currents of rivers flowing in and wind-blown swell. ${ }^{79}$

He continues:

What great fusions of waves and combinations of winds, what boilings and tossings of the Keltic sea (the French army), what a mighty rush and whirlpool of the river Rhine (the Germans), what great seasonal storms and what savage weather! ${ }^{80}$

The violent force of nature motif served many purposes. It was clearly employed to represent the inherent Byzantine perception of the aggressive and disorderly nature notionally intrinsic to the Latin barbarian. Importantly, the poems of Manganeios demonstrate that during the first years of Manuel's reign, both the barbarian topos and the wild and ungovernable force of nature which was the Second Crusade were important themes in the emperor's inaugural

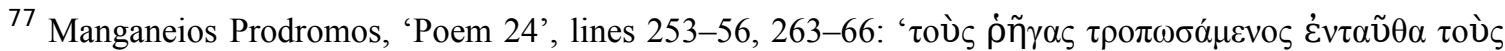

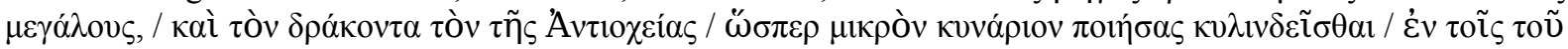

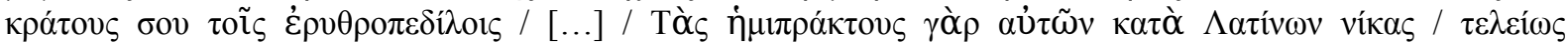

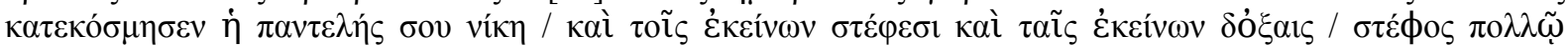

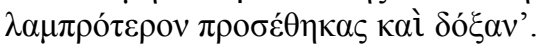

78 John Kinnamos, Deeds of John and Manuel Comnenus, pp. 35-36.

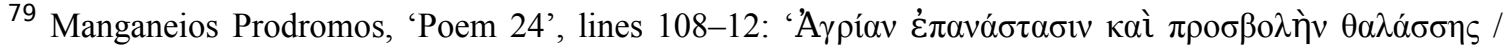

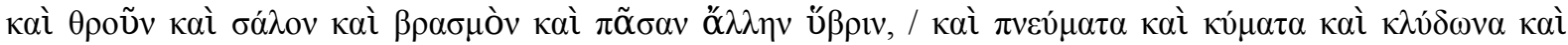

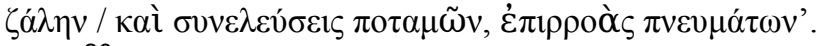

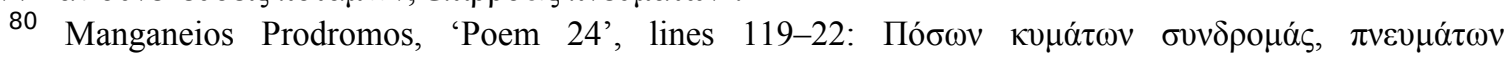

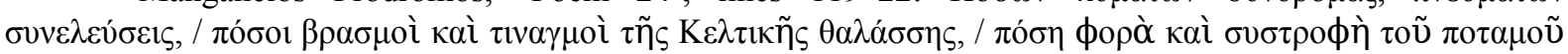

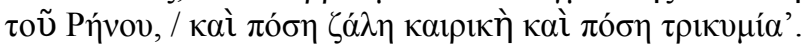


propaganda. This is evident in an explicit statement of the known propaganda purposes underlying this poem and others composed during Manuel's early reign. ${ }^{81}$ Manganeios proclaims:

So just, emperor, is your holding of the empire,

and so worthy the entrusting to you of the helm of power,

that, sitting on high above the empire

like a precise steersman above the stern,

you may deal masterfully with the attacks of the winds,

and steer your city and save her like a ship'. ${ }^{82}$

In poem 24 of the corpus of Manganeios, a relatively lengthy continuous eulogy of Manuel's merits to rule is magnified by a technique that contrasts his galaxy of imperial virtues, which saved Constantinople by driving the crusaders from Pikridion, with some of the conventional negative traits of the Latin barbarians. Manganeios writes:

Hail to your wisdom, hail to your forbearance,

and your patience and your persistence,

and your unsurprised and steadfast heart,

and your firm intellect and brave thoughts!

How did you bear the enemies' insolence?

How did you show patience when they were indisciplined,

How did you refuse to kill the murderers in revenge?

Finally you won the crown for patience;

but they proved ridiculous in their brutality.

You became a new David, patient and meek.

You saw, kings, the emperor, celestial light of New Rome...

a second Solomon, son of the meek David,

and - the most unexpected - you saw a young man's wisdom

as he recompensed his enemies with benefactions.

If you have similar virtue, boast of it;

but if you have just pride, haughtiness and vanity,

then your conceit and lofty words are in vain.

Don't raise your brows vainly, don't show pride, elder Rome.

See, you have realised from your very experience of events

how different your power is from that of New Rome.

So be restrained, don't make vain boasts. ${ }^{83}$

${ }^{81}$ Magdalino, The Empire of Manuel I Komnenos, p. 450.

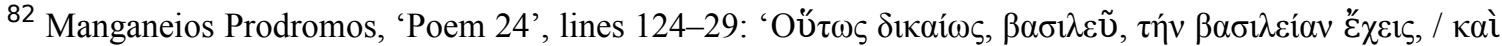

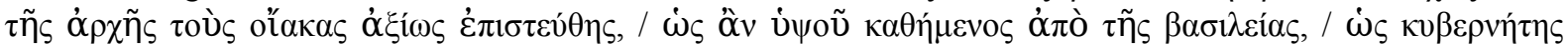

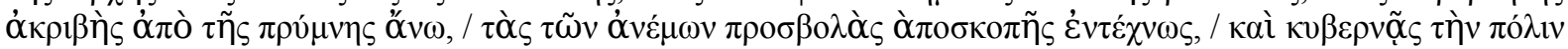

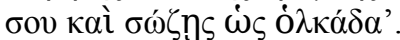

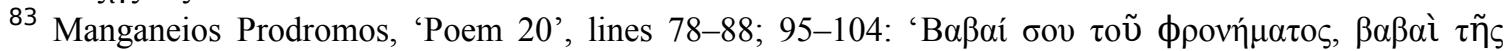

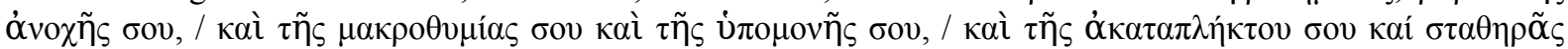

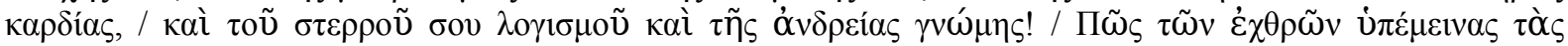

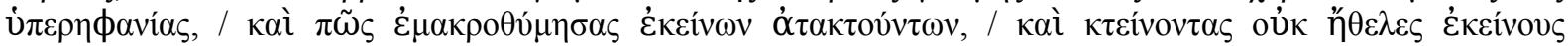

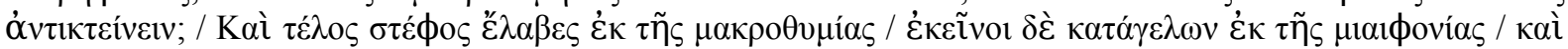

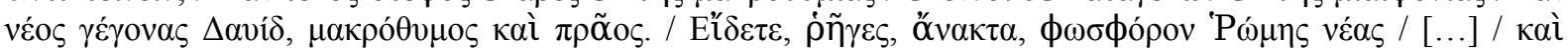

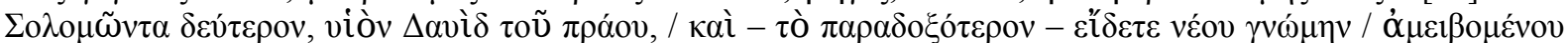

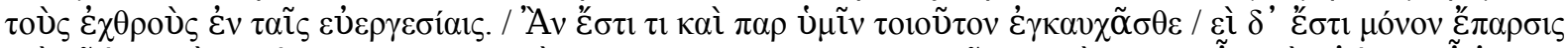

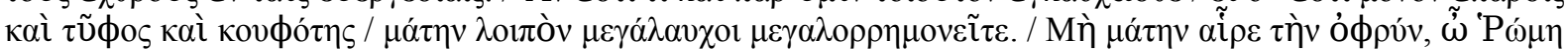
$\pi \rho \varepsilon \sigma \beta \nu \tau \dot{\varepsilon} \rho \alpha$. 
Manuel's propaganda of legitimisation is again countering the convention that the emperor should be a man of mature years. Once more, he is described as naturally in control of his passions, just as the ideal emperor should be. ${ }^{84}$ This notion was an enduringly influential imperial idealisation. It appears to have been employed in Manuel's inaugural propaganda explicitly and implicitly to contrast a calm and contained, though youthful and spirited emperor with the Second Crusade. Put another way, native imperial virtue is contrasted with the perceived stereotypical bestial and uncontrollable forces of nature which were the inherently arrogant and bellicose Latin barbarians of Byzantine rhetoric. Manuel's propagandists exemplified by Manganeios Prodromos are saying: look, while the emperor is young and brave he is gentle. More than that, he his wise and patient; he is truly a new David and Solomon. The emperor's theoretical intelligence frequently drew comparisons with the wisdom of Solomon (and occasionally that of Daniel). ${ }^{85}$ As Manuel was the ideal Christian ruler and the earthly embodiment of Christ divinely ordained to succeed his father, his propagandists are claiming that manifestly the emperor was worthy of his controversial and unusual elevation to the imperial throne. How could it be otherwise, they asked. See how he also saved the city from the brutal folly of the western barbarians who are worse than the most vilified biblical and mythical figures. See how he taught Old Rome the might of New Rome. See how his stratagems defeat the barbarian menace, and his accomplishments far excel his imperial forefathers' victories over the Latins.

As noted earlier, the encomiasts used a process of rhetorical amplification to magnify the significance of events and occurrences the better to reflect the achievements of those being eulogised. And we have just seen that they were prepared to exaggerate the triumphs of previous Komnenoi against the Latin barbarians the better to reflect Manuel's imperial virtue and the right to rule. It therefore seems very likely that the seemingly disorderly conduct of the perceived stereotypical barbarians was likewise inflated to enhance the propagandist image of Manuel's handling of the kings. Caution must obviously be exercised before accepting the representation of the crusaders in the encomia, or for that matter, sources which may be dependent upon the encomiastic tradition.

John Kinnamos was heavily dependent upon this tradition. Importantly, he appears to be at pains to compare and contrast the stereotypical objectionable traits of the Latin barbarians with imperial encomiastic virtues. Kinnamos tells of a letter purportedly written by Conrad to Manuel while the king was still encamped at Pikridion. Part of the letter has Conrad attributing the inevitable small-scale plunder and destruction caused by the Germans forces as they advanced towards Constantinople to 'the impulse of the disorderly mob'. Kinnamos depicts Manuel calmly haranguing Conrad in reply, stating that the perpetually uncontrollable manner of the crusaders had been noted. Manuel supposedly wrote that he had intended to treat the crusaders benignly. However, considering that Conrad could not control his mob, which was allowed to exercise its passions at will, he will follow Conrad's example and not look for ways to suppress the impulse of the Byzantine mob. ${ }^{86}$ Kinnamos thus presents a similar image to that portrayed in contemporary encomia, exemplified by the panegyrics of Manganeios. The encomiast wrote that Conrad was 'inwardly convulsed, roaring like a wild beast' while at Pikridion, and Kinnamos, Manganeios and their respective audiences knew that such animal imagery was a frequently employed and instantly recognisable motif. It denoted the uncultured, reckless, aggressive and undisciplined barbarians, or an impulsive

\footnotetext{
${ }^{84}$ See Magdalino, The Empire of Manuel I Komnenos, p. 416.

85 Magdalino, The Empire of Manuel I Komnenos, p. 447.

${ }^{86}$ John Kinnamos, 'Epitome rerum ab Ioanne et Alexio Comnenis Gestarum', pp. 76-77 and Deeds of

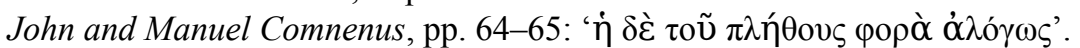


disorderly mob, as Kinnamos prefers to call them here. In contrast, Manuel is in control of his passions and initially intended to treat the crusaders with kindness - just as Manganeios declares that a temperate and benevolent Manuel initially received the crusaders in the manner of David.

Kinnamos suggests that even though Manuel knew his army had fewer soldiers at Pikridion than the crusaders, it was nonetheless superior in military science, and thus he planned as follows. Manuel commanded imperial soldiers to confront the crusaders in battle array. As soon as the crusaders observed this, they were seized 'by great eagerness and disorder' and rushed at the Byzantines. Kinnamos writes that as the crusaders attacked, 'naturally the Romans skilfully resisted' and slew large numbers. ${ }^{87}$ The proud and warlike Conrad remained in camp, apparently unaware of what had befallen the German army. Manuel then seemingly wished to mock Conrad's previous arrogance. He wrote a further letter comparing the crusader army to an uncontrollable horse. He advised the king that military commanders must not allow their soldiers to act according to their natural impulses. Manuel again told Conrad that he wanted to treat the king benevolently, but asked him to consider what had now happened because of the 'disorderliness of the mob. For I learn that a minute army of Romans which encountered an immense number of Germans manhandled them' ${ }^{88}$ Manuel makes it clear that this is because a Byzantine army is superior to any foreign force.

Kinnamos is again relying heavily on the encomiastic tradition here. Once more he stresses that Manuel is kindly in the manner of David. In Manganeios, Conrad rushes at the Byzantines just like the wild impetuous and disorderly rhetorical animal he is, but he is then destroyed by a small detachment of soldiers and the strategy of the emperor ${ }^{89}$ Kinnamos likewise contrasts the perceived uncontrollable, natural belligerence of the western beast with the orderly and methodical Roman 'science of war'. As previously noted, the phrase 'military science' is an encomiastic slogan seemingly employed to accentuate the martial skill of the emperor and his commanders.

According to Kinnamos, Conrad did not pay any attention to Manuel's latest harangue; in fact, he demanded that the emperor provide him with imperial vessels worthy of the king's status to transfer him across the Bosphoros. So Manuel, angered by the 'braggart' ( $\dot{\alpha} \lambda \alpha \zeta o ́ v \alpha)$, wrote to Conrad a third time, advising him that someone with intelligence would perceive that his large army was naturally inferior to the excellence and skill of a Byzantine force. Manuel now compared the crusader army to a weak sparrow or a flock of sheep that would suffer from the attack of a single lion. Kinnamos then has a measured Manuel continuing to lecture Conrad on the German's rightful subordinate place in the world political order, as the events which Kinnamos portrayed suitably demonstrated. In the following sentences of the letter, Manuel appears to shift subject matter abruptly on a number of occasions. First, he tells Conrad that he will never board the imperial galley, but that he must return whence he came. In the next two sentences, Manuel states that he cannot be blamed for taking vengeance against those who have committed wrongful acts. There is another abrupt change of subject matter in the penultimate sentence. Manuel declares that, owing to the previous Byzantine subjugation of the neighbouring lands, the empire will claim any territory

87 John Kinnamos, 'Epitome rerum ab Ioanne et Alexio Comnenis Gestarum', p. 77 and Deeds of John

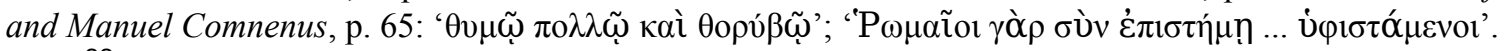

88 John Kinnamos, 'Epitome rerum ab Ioanne et Alexio Comnenis Gestarum', p. 78 and Deeds of John

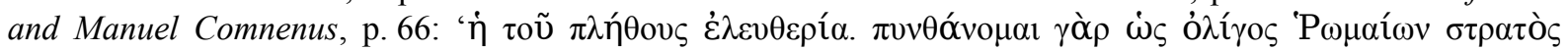

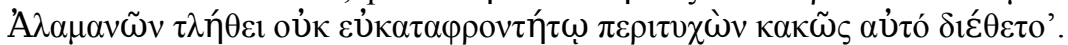

${ }^{89}$ Manganeios Prodromos, 'Poem 20', lines 330-43. 
the crusaders may conquer - although he still writes that the Romans will possess these without difficulty. The last sentence of the letter sees another sharp deviation from the previous subject matter. Manuel tells Conrad that even though the Byzantine populace has demanded an assault on the king, he has refused, although Conrad's arrogance may compel an attack. $^{90}$

This letter reads almost like a checklist of the encomiasts' 'prescribed identikit model'. ${ }^{91}$ There are the frequently employed encomiastic motifs of martial skill, bestial barbarians, the emperor as lion (rather than a wolf, which denoted the crusaders) and Old Rome's subordination to New Rome. ${ }^{92}$ Similar to the encomiastic tradition, Kinnamos also jumps between subject matters that can appear contradictory. Conrad is informed that he will not reach Asia Minor on the imperial galley, but will succeed only in retracing his steps; yet Manuel demands that any conquered territory in Anatolia be subject to Byzantine rule. This appears to betray that Kinnamos, and perhaps the contemporary encomiasts, were actually aware that the crusade was not a pretext for subjugating the empire. Moreover, his statement that Manuel will nevertheless easily recover this territory is very much in line with the propagandist motif of imperial renewal. ${ }^{93}$ With another abrupt shift in subject matter, Manuel tells Conrad that he cannot be blamed for seeking vengeance. This again corresponds with the encomiasts' eulogy of Comnenian militarism and the notion of just war perpetrated against unprovoked aggressors. ${ }^{94}$ The last sentence sees another jump and another contradiction. Even though Manuel commits justified acts of violence, he also refuses to shed the blood of the crusaders despite provocation. The notion of bloodless victories, ${ }^{95}$ and Manuel's patience and naturally ability to control his passions, even when provoked by a typically arrogant barbarian, are all frequently employed encomiastic motifs used in the celebration of Manuel's imperial virtues. Encomiastic conventions greatly influenced the composition of Manuel's last letter to Conrad that is 'reproduced' by Kinnamos.

According to the Byzantine historian, once Conrad had heard Manuel's latest harangue and received news of what befell the crusaders at Pikridion, the king was compelled to cross to the suburb of Damalis on the Asiatic side of the Bosphoros. ${ }^{96}$ The skirmishes and letters 'reproduced' by Kinnamos are seen as evidence of poor diplomatic relations between Conrad and Manuel. ${ }^{97}$ There are many points to consider before continuing to follow this convention. Byzantine contemporaries of the crusade appear to have presumed (incorrectly) that the army's intentions in Byzantine territory were hostile. Such a presumption may have unduly influenced Kinnamos's depiction of the supposed hostility between Conrad and Manuel in his later narrative. Furthermore, at the time Kinnamos wrote his chronicle (c. 1180-82), the Komnenoi and the imperial house of Staufen had been effectively conducting a cold war for over two decades. ${ }^{98}$ Kinnamos's history may merely reflect the current state of hostilities in

90 John Kinnamos, 'Epitome rerum ab Ioanne et Alexio Comnenis Gestarum', pp. 78-80 and Deeds of John and Manuel Comnenus, pp. 66-67.

${ }^{91}$ Magdalino's phrase, see his The Empire of Manuel I Komnenos, p. 451.

92 See Magdalino, The Empire of Manuel I Komnenos, p. 447.

93 See Magdalino, The Empire of Manuel I Komnenos, pp. 418, 421, 450.

94 See Magdalino, The Empire of Manuel I Komnenos, pp. 419-21.

${ }^{95}$ Magdalino, The Empire of Manuel I Komnenos, p. 450.

96 John Kinnamos, 'Epitome rerum ab Ioanne et Alexio Comnenis Gestarum', p. 80 and Deeds of John and Manuel Comnenus, p. 67.

${ }^{97}$ For example, Kugler, Studien zur Geschichte des Zweiten Kreuzzugs, pp. 124-31; Michael Angold, The Byzantine Empire 1025-1204: A Political History, 2nd edn (Harlow, 1997), pp. 195, 198; Kostick, 'Social Unrest and the Failure of Conrad III's March through Anatolia, 1147', pp. 130-31.

${ }^{98}$ Magdalino, The Empire of Manuel I Komnenos, pp. 62-68, 83-95, 98-108. 
the early 1180s. His favourable depiction of the French Second Crusaders (despite evidence to the contrary in 1147) mirrors the good relations between Manuel and King Louis VII of France following the recent betrothal of Manuel's son to the French king's daughter around the very time that Kinnamos was composing his work. ${ }^{99}$ If one follows convention and interprets Kinnamos's narrative irrespective of Byzantine rhetorical practice, his testimony should be read as a reflection of the contemporaneous perceptions of the relations between Conrad and Manuel in 1147. Of course, those later perceptions might not necessarily reflect their relations as projected in most of the contemporaneous Latin texts. ${ }^{100}$

There are further points to consider before accepting Kinnamos's testimony at face value. Manganeios Prodromos wrote that Conrad's 'conceit and lofty words are in vain', and thus gives the impression that Conrad - not surprisingly - was in communication with Manuel. ${ }^{101}$ However, in the words of Kinnamos's editor, 'not one of the letters quoted by Kinnamos can be considered anything but a confection of his own'. The conception of the pseudo-speech and imaginary letter ultimately derives from Thucydides, and was a rhetorical technique employed to set forth one party's position in a dispute. ${ }^{102}$ The imperial harangue was composed in such a manner that it was not intended to deceive the reader or listener. ${ }^{103}$ Kinnamos adapts Thucydides's notion of the imaginary speech to suit his own purpose of portraying the emperor's handling of the crusade in the most favourable light. While Kinnamos's flattering portrayal of the emperor and his subjects is not unique, indeed, such a portrayal was expected in his genre of writing, ${ }^{104}$ it was very much in Kinnamos's interests to ingratiate himself with the Komnenoi. At his time of writing, he was attempting to regain imperial favour and a governmental place in the regency regime of Alexios Komnenos, the Protosebastos for Manuel's son and successor, the young Alexios II. One of Kinnamos's editors maintains that the eulogistic passages in his text are central to the book's very purpose, namely, to curry favour with the regent and the emperor. ${ }^{105}$ Byzantine historians treated the historical genre as a vehicle for imparting their individual and partial perception of the past. ${ }^{106}$ Kinnamos's portrayal of events and explanations of occurrences, while not necessarily untrue, are not objective either. Manuel Komnenos (and by extension his imperial subjects) is depicted in a wholly positive fashion, succeeding over alien invaders, with little attempt made by the author at critical interpretation. His aims were facilitated by the 'reproduction' of fictional letters sent between Manuel and Conrad.

One must also consider that the Latin sources do not recount the clashes near Adrianople and at Pikridion. Whilst a literal reading of Kinnamos, and indeed, Manganeios Prodromos would suggest that the clashes might be serious causes of contention between Conrad and Manuel, surviving German eyewitnesses to those events evidently did not think of them as significant enough to repeat upon their return home. The absence of these episodes in the Latin texts and conversely, the prominent place they demand in Kinnamos's and Manganeios's panegyrics may well reflect the embellishment of events inherent in the verse

99 John Kinnamos, Deeds of John and Manuel Comnenus, p. 4.

100 See for example 'Annales Herbipolenses', p. 5; ‘Annales Palidenses', p. 82; ‘Annales Magdeburgenses', ed. Georg H. Pertz, in MGH SS, 16: 105-96 (188); William of Tyre, Chronique, p. 741; 'Romoaldi II Archiepiscopi Salernitani Annales', ed. Wilhelm Arndt, in MGH SS, 19: 387-461 (here 424).

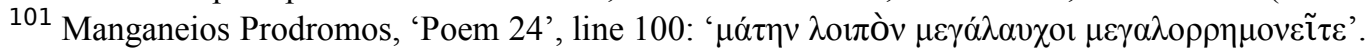

102 See Charles Brand's comments in John Kinnamos, Deeds of John and Manuel Comnenus, p. 7.

103 Chalandon, Jean II Comnène, 1: xxviii.

104 John Kinnamos, Deeds of John and Manuel Comnenus, pp. 8-9.

105 See Brand's comments in John Kinnamos, Deeds of John and Manuel Comnenus, pp. 5, 9.

${ }^{106}$ Magdalino, The Empire of Manuel I Komnenos, pp. 14-15, 18-20. 
encomia. With appropriate evidence, explanations for the clashes and the apparent crusader defeats at Adrianople and Pikridion may be offered in terms of say, logistical necessity, manpower and tactics. But to the Greek authors imbued with the notion of Latin barbarism, both the reason the crusaders clashed with the Byzantines and the reason they were seemingly defeated lay in unrestrained western belligerence and superciliousness. To the Byzantine authors, such barbaric traits inevitably led the crusaders to disregard the prowess of the smaller imperial forces. In contrast to the Latin mode of warfare, the Byzantines were able to combat the errant and impetuous crusaders by martial science rather than brute force. By nature the Latin barbarian was an indisciplined braggart, and just as naturally these traits led to and easily explained both why the crusaders fought and indeed why they were defeated.

It is clear that the crusaders' portrayed invasion of the empire and attack on Constantinople provided appropriate drama for the eulogistic tools of the encomiasts, and that the Byzantine perception of the Latin barbarian provided the encomiasts with a canon of topoi to contrast with imperial virtue. Through the repetition of particular themes and motifs central to Manuel's inaugural propaganda and the use of techniques such as synkrisis and rhetorical amplification, the crusade and crusaders are employed as foils to legitimise the emperor's right to rule. In consequence, there are implications for the current historiography that is based predominantly on the well-known history of John Kinnamos. There is parity between the accounts of Kinnamos and Manganeios which may suggest both had access to a common fund of perhaps official information to compose their works. However, the Greek historians also employed contemporary encomia as sources for their narratives. John Kinnamos was more inclined than Niketas Choniates to reproduce encomiastic techniques, motifs and versions of events as found in the encomia. ${ }^{107}$ One cannot know whether Kinnamos actually did employ contemporary encomia to compose his history of the crusade, let alone if he had access to the panegyrics of Manganeios. Nonetheless, the significant influence of encomiastic motifs and themes found in Kinnamos's history demonstrates that Kinnamos relied heavily on encomiastic tradition. At the very least, he employed that tradition to pursue his own agenda of regaining imperial favour and a governmental place with the Komnenoi. He himself had been an encomiast and therefore was not only imbued with encomiastic techniques and vocabulary, but also understood how they could be made to work most effectively. If Kinnamos employed an encomiastic tradition that has been shown to make use of rhetorical amplification for imperial propaganda, his portrayal of crusader belligerence, disorder and poor relations with the emperor, which form the basis of the current historiography, is likely to have been subject to hyperbolical distortion. His history of the crusade must therefore be interpreted with similar reservations to those one would use in the interpretation of verse encomia.

To highlight this issue is not a direct criticism of Kinnamos's history of the Second Crusade. Given his intended audience, perhaps his testimony should be considered an official, sanctioned perception and conventional representation of the events and occurrences of thirtyfive years earlier. The influence of the Byzantine rhetorical conventions must, however, be taken into account. The lack of supporting evidence for the clashes and hostilities which Kinnamos reports, evidence to the contrary in the less accessible sources, and his personal reasons for extolling the emperor should also be considered. Historians must exercise extreme caution before employing Kinnamos's evidence of German arrogance, belligerence and indiscipline. This is not to argue that the German army was not bellicose, or did not commit acts of disorder, any more than it is to say that Manuel Komnenos did not have praiseworthy virtues. Notwithstanding the inevitable disruption caused by the passage of a large medieval

${ }^{107}$ Magdalino, The Empire of Manuel I Komnenos, p. 445. 
army, the problematic nature of the sources that tell of the German disorder has to be recognised and must be acknowledged. ${ }^{108}$ Reiterating the historiography of the nineteenth century and its literal reading of Kinnamos's work is certainly problematic. ${ }^{109}$

There is no comparable evidence in the work of Niketas Choniates of hostility between Manuel, Conrad, and their respective forces at Constantinople. Interestingly though, there is evidence of the encomiastic tradition in his narrative. This may be a consequence of Choniates's experience as an encomiast, or perhaps his use of encomia as sources of information which he employs rather more selectively than the uncritical Kinnamos. If the crusaders were responsible for the hostilities at Pikridion, Choniates's omission of the conflict may again betray his own agendum. ${ }^{110}$ His interpretation of the skirmish near Adrianople and the flood on the plain of Choirobacchoi were perhaps influenced by his interpretation of divine providence that witnessed God's transferral of His favour from the Byzantines to the western barbarians. Does Choniates's omission of the skirmish at Pikridion reflect that his original sources held the crusaders responsible for the clash, and that he chose therefore to omit it from his narrative? Either way, Choniates's subjective interpretation of divine providence provides us with another perspective on events. It seems that his descriptions of the clash at Adrianople and the flood at Choirobacchi were intended to act as a corrective to the partial evidence of contemporary encomia.

One important act of revision to received interpretations in Constantinople raises an interesting question. Choniates stated that the crusade was not a pretext to conquer Byzantine territory. ${ }^{111}$ Kinnamos's last imaginary letter written by Manuel to Conrad seems to betray that Kinnamos, and perhaps contemporary encomiasts knew that the seizure of Byzantine territory was not an aim of the crusade, as later events were to prove. Manuel's preparations for receiving the crusade at Constantinople, and the circulation of prophecies of the destruction of the city demonstrate that the crusade was perceived as a threat. The German and French disorder en route to Constantinople would only have reinforced preconceived fears that the armies' intentions were hostile to those inherently predisposed to the notion of Latin barbarism. Contemporary encomia undoubtedly portray such notions. ${ }^{112}$ But Choniates's statements and Kinnamos's contradiction, coupled with the practice of rhetorical amplification which sought to portray the crusaders' intentions in the worst possible light, strongly suggests that the crusaders' threat to Constantinople, as well as the crusaders' conduct, was exaggerated in Kinnamos and Manganeios the better to portray Manuel Komnenos's supposed defeat of the barbarian menace. When this is taken into consideration, it becomes difficult to discern whether their portrayal of the crusader threat reflected actual or embellished concerns. Did Manganeios's and Kinnamos's statements that the crusade was a barbarian act of war reflect common perceptions, or were they the product of rhetorical amplification and, ultimately, sanctioned Comnenian propaganda in 1147 and 1180-1182 respectively? ${ }^{113}$

${ }^{108}$ Compare with Kostick, 'Social Unrest and the Failure of Conrad III's March through Anatolia, 1147', pp. 130-31, n. 25. In his bid to demonstrate that 'social unrest' somehow caused the failure of the German advance in Anatolia, Kostick ignored the critique of John Kinnamos's work found in Roche, 'Conrad III and the Second Crusade in the Byzantine Empire and Anatolia, 1147', esp. pp. 55-60, 63-64, 79-83, 85-88.

109 Compare Kugler, Studien zur Geschichte des Zweiten Kreuzzugs, pp. 119-47 with Kostick, 'Social Unrest and the Failure of Conrad III's March through Anatolia, 1147', esp. pp. 130-33.

${ }^{110}$ Niketas Choniates, Nicetae Choniatae Historia, 1: 65-66 and O City of Byzantium, p. 38.

111 Niketas Choniates, Nicetae Choniatae Historia, 1: 61 and O City of Byzantium, pp. 35-36.

112 Manganeios Prodromos, 'Poem 24', lines 53-54; Michael the Rhetor, 'Oratio ad Manuelem Imperatorem', p. 173; Eusthathios of Thessalonica, 'Orationes’ pp. 105-6. 
One thing is certain. Whilst Manuel's propagandists wished to foster an impression of hostile crusader intent, the emperor's behaviour reveals something quite different. The Komnenoi and the Hohenstaufen strengthened their existing dynastic bonds with the marriage of Conrad's ally and relative, Henry II Jasomirgott, the duke of Bavaria, to Manuel's niece Theodora in 1148. ${ }^{114}$ Manuel and Conrad may have confirmed an earlier agreement during the king's return from crusade by way of the so-called 'Treaty of Thessalonica'. ${ }^{115}$ The monarchs discussed bringing the dynasties even closer by way of a marriage between one of Manuel's female relatives and Conrad's son and heir, Henry. Upon Henry's death in 1151, Conrad offered himself as a suitor to draw the dynasties closer still. ${ }^{116}$ The monarchs were allied before the crusade, and the two rulers clearly continued to consider themselves as allies during and after Conrad's prolonged interlude in the empire. This reality, of course, is in stark contrast to that presented in the distorted testimonies of Manganeios and Kinnamos, even if perhaps the alliance was rooted in Realpolitik rather than purely the Hohenstaufen's familial bonds with the Komnenoi.

113 Of course, the imperial propaganda machine may not have sanctioned Manganeios's encomia. Manganeios occasionally had cause to complain that the emperor took no notice of his poems. See Michael Jeffreys, "'Rhetorical” Texts', in Rhetoric in Byzantium, ed. Jeffreys, pp. 87-100, esp. p. 94.

114 See, for example, 'Annales Palidenses', p. 83.

115 John Kinnamos, 'Epitome rerum ab Ioanne et Alexio Comnenis Gestarum', p. 87 and Deeds of John and Manuel Comnenus, p. 72; Otto of Freising, Gesta Frederici, I.65 (pp. 264-67) and The Deeds of Frederick Barbarossa, p. 103; 'Annales Palidenses', p. 83; John of Salisbury, The Historia Pontificalis of John of Salisbury, ed. and trans. Marjorie Chibnall (Oxford, 1986), p. 59; 'Romoaldi II Archiepiscopi Salernitani Annales', p. 424. On the so-called 'Treaty of Thessalonica' see Hanna Vollrath, 'Konrad III. und Byzanz', Archiv für Kulturgeschichte 59 (1979), 321-65; Rudolf Hiestand, 'Neptis tua und fastus Graecorum. Zu den deutsch-byzantinischen Verhandlungen 1150', Deutsches Archiv für Erforschung des Mittelalters 49 (1993), 502-55.

${ }^{116}$ Vollrath, 'Konrad III und Byzanz', pp. 358-63. 